\title{
Physiological potential of wheat seeds produced under light restriction
}

\author{
Camila Cigel ${ }^{1} \odot$, Clovis Arruda Souza ${ }^{1 *} \odot$, Rodrigo Kandler $^{1} \odot$, Elijanara Raissa Silva ${ }^{1} \odot$, \\ Cileide Maria Medeiros Coelho' ${ }^{1}$, Cristiane Segatto ${ }^{1}[0$

\footnotetext{
${ }^{1}$ Santa Catarina State University, Lages, SC, Brazil. E-mail: camilacigel@gmail.com; souza_clovis@yahoo.com.br; eng.kandler@hotmail.com; raissa@agronoma.eng.br; cileidecoelho@yahoo.com.br; segattobio@gmail.com
}

ABSTRACT: The low radiation intensity can negatively affect the production of photoassimilates in plants for allocation and synthesis of reserves into seeds. This study aimed to evaluate the physiological quality of wheat seeds produced by plants imposed on conditions of light reduction in different phenological stages, remaining until the end of the cycle. The experiment was carried out in a greenhouse in 2018, with a completely randomized design, with 11 treatments and 20 repetitions. The treatments consisted of 11 seed lots: 10 of plants grown in artificial shade (70\%) started in the Zadoks code's phenological stages: 23; $30 ; 35 ; 45 ; 55 ; 60 ; 65 ; 70 ; 75 ; 80$ and control lot (without shading). The seeds were analyzed for germination and vigor. Seed germination was not affected. There was a reduction in vigor through the tests of accelerated and cold aging when the shading started between stages 55 and 65 , but with a minimum vigor of 93 and $94 \%$, respectively. It is concluded that the restriction of light during the development of wheat plants does not affect the germination of the seeds produced but impairs the vigor mainly when imposed in the reproductive phases.

Key words: low light intensity; photosynthesis; shading; Triticum aestivum L.; vigor

\section{Potencial fisiológico de sementes de trigo produzidas sob condições de restrição luminosa}

RESUMO: A baixa intensidade de radiação pode afetar negativamente a produção de fotoassimilados nas plantas para a alocação e síntese de reservas nas sementes. Objetivou-se neste estudo avaliar a qualidade fisiológica de sementes de trigo produzidas por plantas impostas a condições de redução da luz em diferentes estágios fenológicos, permanecendo até 0 final do ciclo. 0 experimento foi realizado em casa de vegetação em 2018, com delineamento experimental inteiramente casualizado, com 11 tratamentos e 20 repetições. Os tratamentos consistiram em 11 lotes de sementes: 10 de plantas cultivadas em sombra artificial (70\%) iniciados nos estágios fenológicos (códigos de Zadoks): 23; 30; 35; 45; 55; 60; 65; 70; 75; 80 e lote testemunha (sem sombreamento). As sementes foram analisadas quanto à germinação e vigor. A germinação das sementes não foi afetada. Houve redução do vigor através dos testes de envelhecimento acelerado e frio foi quando o sombreamento iniciou entre os estágios 55 e 65, mas com um vigor mínimo de 93 e 94\%, respectivamente. Conclui-se que a restrição da luz durante o desenvolvimento das plantas de trigo não afeta a germinação das sementes produzidas, mas prejudica 0 vigor principalmente quando imposto nas fases reprodutivas.

Palavras-chave: baixa intensidade luminosa; fotossíntese; sombreamento; Triticum aestivum L.; vigor

\footnotetext{
${ }^{*}$ Clovis Arruda Souza - E-mail: souza_clovis@yahoo.com.br (Corresponding author)

Associate Editor: Edna Ursulino Alves
} 


\section{Introduction}

Wheat (Triticum aestivum L.) is the second most produced cereal worldwide, with world production of 731.62 million tons in the 2018 season (FAO, 2020). In Brazil, the annual production was 5.4 million tons in the same year, according to data from the National Supply Company (Conab, 2020).

The satisfactory growth and productivity of agricultural crops is dependent on local environmental conditions, among which the importance of luminosity stands out. It is indispensable in the photosynthetic process for the production of photoassimilates by plants, required for vegetative growth and development of reproductive organs of agronomic interest, such as seeds (Marcos Filho, 2015).

Low light incidence conditions are related to factors intrinsic and extrinsic to the crop, as well as conditions of greater plant density in sowing, latitude, seasons, integrated crop-forest systems and less hours of sunshine or greater cloudiness (daytime cloudiness index), that normally occur in the high fields in Rio Grande do Sul and Santa Catarina even in the months of June, July and August (Custódio et al., 2009). In this way, the development of crops, such as wheat, can be compromised.

In wheat, some studies point out the reduction of the photosynthetic rate ( $\mathrm{Mu}$ et al., 2010) as the main negative effect of shading, resulting in less biomass production under conditions of $50 \%$ reduction in luminosity (Asseng et al., 2017). However, other authors have observed increase in grain yield in low-intensity shading, due to the delay in wheat leaf senescence (Xu et al., 2016; Arenas-Corraliza et al., 2019) and increase in leaf area and growth index the plants (Li et al., 2010; Arenas-Corraliza et al., 2019).

However, there are no studies that assess the physiological quality of cereal seeds produced in shade conditions. In canola, a smaller number of grains per plant being compensated in greater weight per grain under shading conditions (Labra et al., 2017). Regarding seed quality, Bellaloui et al. (2012) found an increase in germination in most tested soybean cultivars, with a $50 \%$ limitation in the reduction of light. However, under conditions of restricted lighting, in the aforementioned surveys, a reduction in grain yield was observed. Therefore, the definition of the sowing schedule can be an escape from the occurrence of light restriction, especially in critical stages (between anthesis and seed filling), both for grain yield and the seed quality to be produced.

Studies related to the characterization of the seed quality produced under conditions of low level of light incident on crops during their development are scarce. Thus, based on the hypothesis that longer periods of shading during the development of wheat plants cause a reduction in the physiological seed quality, the objective was to evaluate the physiological quality of wheat seeds produced by plants growing in $70 \%$ light reduction (continuous) at different phenological stages.

\section{Materials and Methods}

The study was carried out in a greenhouse during 2018, at the Center for Agroveterinary Sciences, of the Santa Catarina State University (CAV/UDESC) in the municipality of Lages, SC, Brazil, located under geographical coordinates $27^{\circ} 52^{\prime}$ South Latitude, $50^{\circ} 18^{\prime}$ West Longitude and average altitude of $930 \mathrm{~m}$.

Sowing was carried out on April 16, 2018 corresponding to Julian Day (JD) number 106. A photoperiod suitable for the species was used, with constant complementary artificial lighting during the crop cycle, with 10 hours of darkness and 14 hours of light. 10 seeds were sown per pot, followed by thinning, maintaining only 5 plants in each pot. For seed treatment, a commercial product based on pyraclostrobin + thiophanate- methyl + fipronil (Standak Top, $5 \mathrm{~g}$ a.i. ha-1 $+45 \mathrm{~g}$ a.i. $\mathrm{ha}^{-1}+50 \mathrm{~g}$ a.i. ha-1) was used. Daily irrigation was performed manually, according to the requirement of the plants. The temperature and relative humidity $(\mathrm{RH})$ records, made by the Datalogger (TENMARS, TM305U) of the greenhouse, during the crop growing season, are shown in Figure 1.

Based on the interpretation of the results of the soil analysis, liming and fertilization was carried out, according to recommendations of the Soil Chemistry and Fertility Commission (CQFS RS/SC, 2016), corresponding to 6.8 tons per hectare of limestone, and the fertilization with $20.74 \mathrm{~kg}$ ha- of $\mathrm{K}_{2} \mathrm{O}$ and $31.32 \mathrm{~kg} \mathrm{ha}^{-1}$ of $\mathrm{P}_{2} \mathrm{O}_{5}$ and $60 \mathrm{~kg} \mathrm{ha}^{-1}$ of nitrogen (urea), being divided into base and cover applications. The cover fertilizations were carried out at stage 20 (beginning of tillering - JD117), according to the scale of Zadoks et al. (1974), and at stage 30 (start of elongation of the stem-JD 131), using $0.5 \mathrm{~g}$ of urea and $0.5 \mathrm{~g}$ of $\mathrm{KH}_{2} \mathrm{PO}_{4}$ (Anhydrous Potassium Monobasic Phosphate) per pot. For phytosanitary treatments,

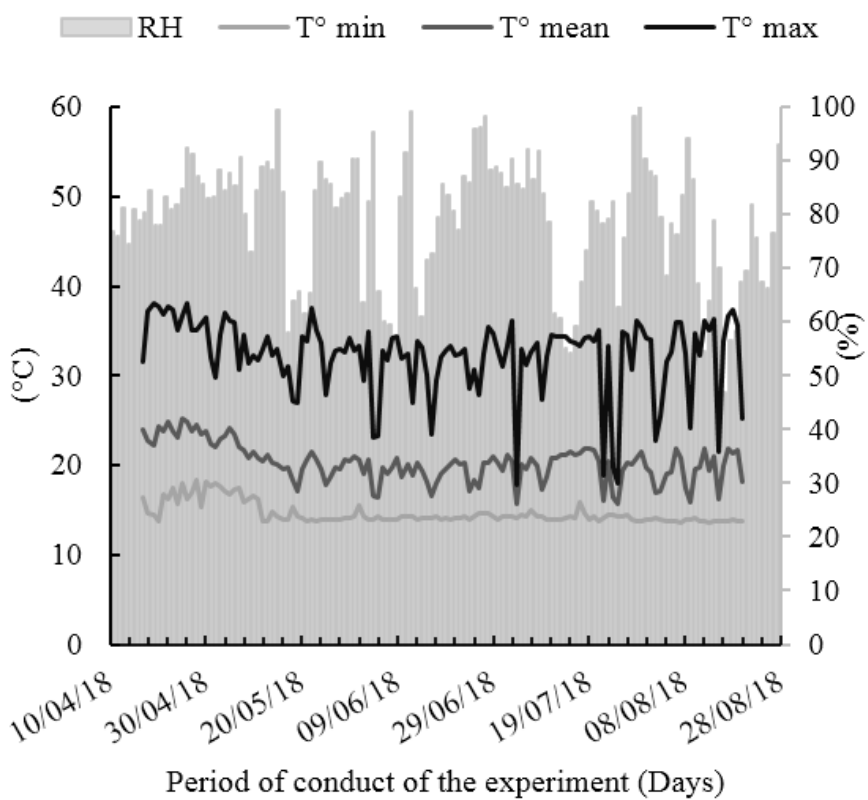

Figure 1. Averages of relative humidity $(\mathrm{RH})$ and temperatures (minimum - $\mathrm{T}^{\circ}$ min, mean $-\mathrm{T}^{\circ}$ mean and maximum $-\mathrm{T}^{\circ}$ max) recorded in the greenhouse during the experimental wheat cropping, during the 2018 season. 
applications of trifloxystrobin + tebuconazole (Native $60 \mathrm{~g}$ a.i. $\mathrm{ha}^{-1}+120 \mathrm{~g}$ a.i. ha ${ }^{-1}$ ) and thiamethoxam + lambda-cyhalothrin (Engeo Pleno, $5.64 \mathrm{~g}$ a.i ha-1 $+4.24 \mathrm{~g}^{\text {a.i. }} \mathrm{ha}^{-1}$ ) on May 25 (JD 145); metconazole (Caramba, $72 \mathrm{~g}^{\text {a.i. }}$ ha $^{-1}$ ) on June 28 (JD 179); and trifloxystrobin + cyproconazole (Sphere Max, 92.75 g a.i. ha ${ }^{-1}+40$ g a.i. ha ${ }^{-1}$ ) on July 30 (JD 211), for powdery mildew control (Blumeria graminis $\mathrm{f}$. sp. tritici).

Artificial shading was imposed on plants with the use of black colored shade net with $70 \%$ fiber density, allowing only $30 \%$ of the available solar radiation to be exceeded (conferred via PAR- Photosynthetically Active Radiation and PPFD-photosynthetic photon flux density). The shade net was installed on a $1.50 \mathrm{~m}$ high wooden structure, necessary to house the pots containing the plants on all net sides.

Harvesting was carried out when the seeds were in the harvest maturity, on August 20, 2018, corresponding to JD 232. After the manual threshing of the ears, the seeds were dried in a forced air convection oven at $35^{\circ} \mathrm{C}$ until their mass stabilized, standardizing humidity close to $13 \%$. After that, the seeds of the plants in the pots of each treatment were homogenized, forming the respective seed lots as the average sample, and subsequently separated into 4 repetitions to compose the working samples.

The experiment was conducted in a completely randomized design with 11 treatments and 20 replicates. The treatments consisted of 11 seed lots. Ten seed lots originated from plants that artificial shading condition of $70 \%$ of the light was imposed, at different phenological stages, according to the scale of Zadoks et al. (1974), being: 23 (tillering - 3rd week after emergency - WAE); 30 (start of elongation of the culm 4th WAE); 35 (fifth visible node - 5th WAE); 45 (full rubber - 6th WAE); 55 (half of the emerged inflorescences - 7th WAE); 60 (beginning of anthesis- 8th WAE); 65 (half of complete anthesis - 9th WAE); 70 (beginning of the 10th SAE grain development); 75 (milky grain - 11th WAE); 80 (beginning of the development of grain in mass - 12th WAE). A control treatment was also established with plants that shading was not imposed (Figure 2). Each experimental plot was composed of a unique pot containing five wheat plants of the cultivar Esporão, category C1, cycle of 128 days, average height of $90 \mathrm{~cm}$, moderately resistant to lodging and moderately susceptible to powdery mildew.

\section{Evaluated characteristics}

The following analyzes were proceeded:

- Thousand Seeds Weight (TSW): weighing eight repetitions of 100 seeds. Each replicate was weighed and multiplied by 10 (Brasil, 2009);

- Germination Test (G): eight replicates of 50 seeds for each treatment, distributed between sheets of specific paper (Germitest ${ }^{\circ}$ ) previously moistened with deionized water using an amount equivalent to 2.5 times its weight; left in the germinator for eight days at a temperature of $20^{\circ} \mathrm{C}$, evaluating the percentage of normal seedlings (G) abnormal (Ab) and dead seeds (DS) at the end of the period (Brasil, 2009).

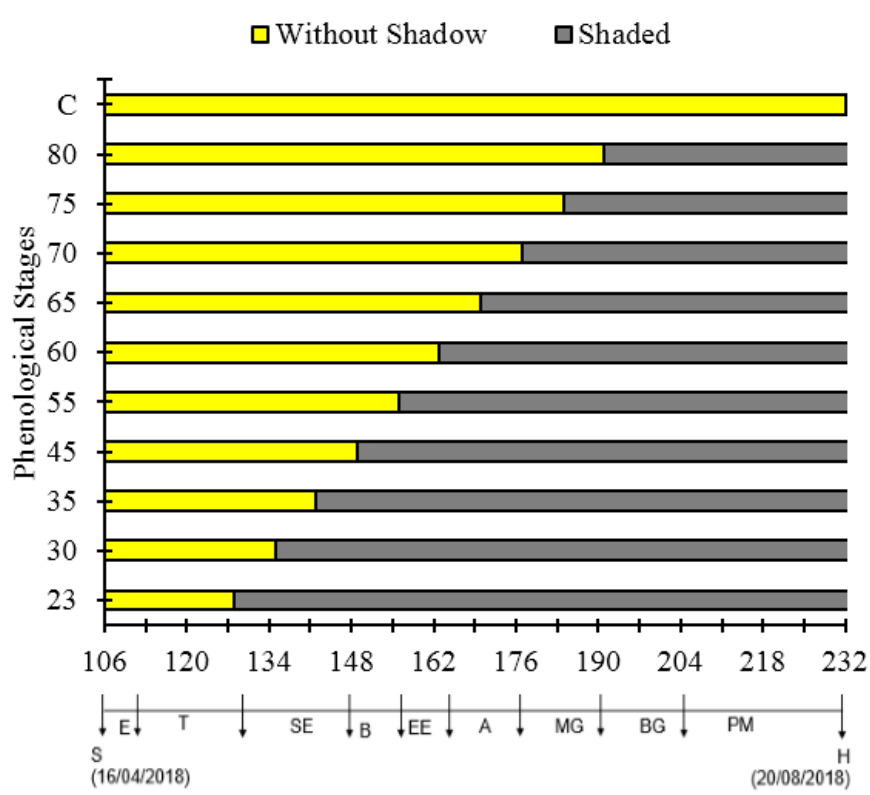

Julian Days / Phenological stages

Figure 2. Representation of the phenological stages of beginning of the condition of light restriction imposed on wheat plants to obtain seed lots. Sowing (S); Emergency (E); Tillering (T); Stem elongation (SE); Booting (B); Emergency of the Ear (EE); Anthesis (A); Milky Grain (MG); Bulk grain (BG); Physiological Maturity (PM); Harvest (H). C: Control Treatment.

For abnormal seedlings and dead seeds, data were transformed into $((x+1,5) / 100)^{0,5}$;

- $\quad$ First Germination Count (FGC): percentage of normal seedlings at four days after the start of the germination test (Krzyzanowski et al., 1999);

- Germination Speed Index (GSI): daily count (24 h intervals) of normal seedlings germinated over the duration of this germination (Maguire, 1962);

- $\quad$ Accelerated Aging (AA): 400 seeds per treatment, kept at $42{ }^{\circ} \mathrm{C}$, under $100 \%$ humidity for $60 \mathrm{~h}$ (Krzyzanowski et al., 1999), and submitted to the germination, with evaluation at eight days;

- Cold Test (CT): eight replicates of 50 seeds, maintained at a temperature of $10{ }^{\circ} \mathrm{C}$ during seven days (Krzyzanowski et al., 1999), following for germination, and evaluated a eight days;

- Electrical Conductivity (EC): four replicates of 50 seeds per treatment, added to $75 \mathrm{~mL}$ of deionized water, for $24 \mathrm{~h}$ at a temperature of $25^{\circ} \mathrm{C}$, and measurement of the EC with a bench conductivity meter (Quimis, Model 0795A2). The results in expressed as $\mu \mathrm{S} \mathrm{g}^{-1} \mathrm{~cm}^{-1}$ (Krzyzanowski et al., 1999);

- Tetrazolium: four replicates of 50 seeds placed between three sheets of Germitest ${ }^{\circledR}$ paper, moistened with 2.5 times their weight, and kept for $18 \mathrm{~h}$ at a temperature of $20^{\circ} \mathrm{C}$, to perform the pre-wetting. Afterwards, the seeds were cut, through a longitudinal bisection along the embryo and in $3 / 4$ of the endosperm; soaked in a solution of $0.5 \%$ chloride of 2,3,5 triphenyl tetrazolium during 3 hours, and then classified as viable and non- 
viable, according to the color of the embryo (Brasil, 2009). The results were expressed as a percentage of viable seeds (Brasil, 2009);

- Shoot Length (SLS); Seedling main Root Length (SRL); and Total Seedling Length (TSL): on the fifth day of the germination test (Brasil, 2009), the aerial part (shoot), main root of 20 wheat seedlings, was measured, with eight replicates per treatment (Krzyzanowski et al., 1999);

- Seedling dry weight (SDW): drying in a forced air oven at a temperature of $65{ }^{\circ} \mathrm{C}$ until its mass stabilizes (Krzyzanowski et al., 1999).

\section{Statistical analysis}

Data were firstly subjected to normality and homogeneity tests, and, subsequently, to the analysis of variance by the $F$ test $(p<0.05)$, with the percentage transformed into a arcsin of $(x / 100)^{0.5}$. If there was a significant difference, the averages of the lots were compared by the Skott-Knott test $(p<0.05)$, using the statistical software Sisvar (Ferreira, 2011).

\section{Results}

No statistically significant difference was observed $(p>$ 0.05 ) for germination $(G)$, percentage of abnormal seedlings $(A B)$, dead seeds (DS) and viability by the tetrazolium test for seed lots from wheat plants grown under shading started at different phenological stages (Figure 1 and Table 1).

The thousand seeds weight (TSW) of the seed lots from shaded plants showed lower means than the control ( $38.7 \mathrm{~g}$ ), except for the seed lot obtained from shading from stage 35 (Zadoks et al., 1974) (Table 1). The seed lots corresponding to the stages of onset of shading in 23, 30 and 35 showed an increase of $34.5,54.9$ and $74.3 \%$, respectively, when compared to those produced by shaded plants from stage 60 (anthesis) with $21.3 \mathrm{~g}$. A more intense negative effect was observed in the TSW of seeds produced by shaded plants between phenological stages 45 and 65 (booting and half of complete anthesis), whose reduction varied from 53.4 to $81.5 \%$, compared to the control ( $38.7 \mathrm{~g}$ ).

For the assessment of vigor by the first germination count test (FGC), significant higher values were observed for seed lots from wheat plants imposed on shading in phenological stages 23, 30 and 35 (tillering at fifth visible node), and 80 (grain by mass), with percentages of germination between 94 and $96 \%$. These lots showed greater vigor than the control (without shading) by the test, whose percentage of normal seedlings in the FGC was by $81 \%$. As for the batches obtained from shading starting at stages 45 to 75 (booting with milky grain), there was no difference with the control.

Germination speed index (GSI) for seed lots obtained from plants with shading starting at stages 23 (tillering), 30 and 35 (stem elongation) and 80 (grain mass) showed higher results than the control (11.8), with an average increase of $4.4 \%$ in the index. The seeds of the lots corresponding to the shading period started between stages 45 (rubber) and 75 (milky grain) did not differ from the control.

Electrical conductivity (EC) showed significant higher values than the control for all the lots of wheat plant seeds submitted to shading in different phenological stages, characterizing their lower vigor (Table 1). The seed lot obtained from the shaded plants from stage 55 (half of the emerged inflorescence) showed a higher EC value $(60.3 \mu \mathrm{S}$ $\mathrm{g}^{-1} \mathrm{~cm}^{-1}$ ), representing an increase of $84.5 \%$ in relation to the seeds produced by wheat plants without shading (control) whose $\mathrm{EC}$ value was $32.7 \mu \mathrm{S} \mathrm{g}^{-1} \mathrm{~cm}^{-1}$.

Seed vigor verified by the AA test showed the lowest percentages, varying from 93 to $98 \%$, for the plant lots growing in the shading condition from stage 45 (booting), 60 and 65 (anthesis), respectively (Table 2). In the cold test (CT) a reduction in seed vigor was observed only for the lot of seeds obtained from wheat plants produced under the condition of

Table 1. Thousand seed weight (TSW), first germination count (FGC), germination (G), abnormal seedlings (AB), dead seeds (DS), viability by tetrazolium (TZ), germination speed index (GSI) and electrical conductivity (EC) of wheat seeds produced under different periods of shading.

\begin{tabular}{|c|c|c|c|c|c|c|c|c|}
\hline \multirow{2}{*}{$\begin{array}{c}\text { Phenological } \\
\text { stages }\end{array}$} & \multirow{2}{*}{$\begin{array}{c}\text { TSW } \\
\text { (g) }\end{array}$} & FGC & $\mathbf{G}$ & $A B$ & DS & TZ & \multirow{2}{*}{ GSI } & \multirow{2}{*}{$\begin{array}{c}\text { EC } \\
\left(\mu S \mathrm{~g}^{-1} \mathrm{~cm}^{-1}\right)\end{array}$} \\
\hline & & \multicolumn{5}{|c|}{ (\%) } & & \\
\hline 23 & $28.71 \mathrm{c}$ & $96 a$ & $99 \mathrm{~ns}$ & $1^{\mathrm{ns}}$ & $0^{\mathrm{ns}}$ & $99 \mathrm{~ns}$ & $12.34 \mathrm{a}$ & $50.3 \mathrm{~b}$ \\
\hline 30 & $33.07 \mathrm{~b}$ & $96 a$ & 100 & 0 & 0 & 100 & $12.33 a$ & $42.4 \mathrm{C}$ \\
\hline 45 & $25.26 \mathrm{~d}$ & $88 \mathrm{~b}$ & 99 & 1 & 0 & 99 & $12.03 \mathrm{~b}$ & $54.4 \mathrm{~b}$ \\
\hline 55 & $23.88 \mathrm{~d}$ & $88 b$ & 98 & 1 & 1 & 96 & $12.05 \mathrm{~b}$ & $60.3 \mathrm{a}$ \\
\hline 70 & $27.52 c$ & $90 \mathrm{~b}$ & 99 & 1 & 0 & 99 & $12.09 \mathrm{~b}$ & $44.4 \mathrm{C}$ \\
\hline 75 & $28.42 \mathrm{c}$ & $90 \mathrm{~b}$ & 99 & 1 & 0 & 99 & $12.03 \mathrm{~b}$ & $45.5 \mathrm{c}$ \\
\hline 80 & $32.49 \mathrm{~b}$ & $96 a$ & 99 & 1 & 0 & 99 & $12.33 \mathrm{a}$ & $43.8 \mathrm{c}$ \\
\hline C & $38.75 \mathrm{a}$ & $81 b$ & 99 & 1 & 0 & 99 & $11.81 \mathrm{~b}$ & $32.7 \mathrm{~d}$ \\
\hline LSD & 5.24 & 8.5 & 2.3 & 1.9 & 1.2 & 2.8 & 0.4 & 10.1 \\
\hline CV (\%) & 12.4 & 7.9 & 5.5 & 29.1 & 20.2 & 5.2 & 2.3 & 10.4 \\
\hline
\end{tabular}

* Same letters in the column do not differ from each other by the Skott-Knott test at $p<0.05$. ns: not significant (p $>0.05)$. C: Control Treatment; LSD: least significant difference; CV (\%): Coefficient of variation. 
Table 2. Accelerated aging (EA), cold test (CT), main root length (RL), aerial part (SL - shoot), total (TSL) and seedling dry weight (SDW) of wheat seeds produced under different periods of shading.

\begin{tabular}{|c|c|c|c|c|c|c|}
\hline \multirow{2}{*}{$\begin{array}{l}\text { Phenological } \\
\text { stages }\end{array}$} & AA & CT & $\mathrm{RL}$ & $\mathrm{SL}$ & TSL & \multirow{2}{*}{$\begin{array}{c}\text { SDW } \\
\left(\mathrm{mg} \mathrm{pl}^{-1}\right)\end{array}$} \\
\hline & \multicolumn{2}{|c|}{ (\%) } & \multicolumn{3}{|c|}{ (cm) } & \\
\hline 23 & $99 a$ & $100 \mathrm{a}$ & $19.06 \mathrm{~b}$ & $15.4 \mathrm{~b}$ & $34.47 \mathrm{~b}$ & $20.88 c$ \\
\hline 30 & $100 \mathrm{a}$ & $100 \mathrm{a}$ & $21.03 \mathrm{a}$ & $14.83 b$ & $35.86 \mathrm{a}$ & $25.99 b$ \\
\hline 35 & 99 a & $100 \mathrm{a}$ & $20.80 \mathrm{a}$ & $14.81 \mathrm{~b}$ & $35.62 \mathrm{a}$ & $24.46 b$ \\
\hline 45 & 99 a & $99 a$ & $20.32 \mathrm{a}$ & $14.68 b$ & $35.00 \mathrm{~b}$ & $20.51 c$ \\
\hline 55 & $98 \mathrm{~b}$ & $100 \mathrm{a}$ & $20.33 \mathrm{a}$ & $14.47 \mathrm{~b}$ & $34.81 \mathrm{~b}$ & $19.56 \mathrm{c}$ \\
\hline 60 & $93 c$ & $96 \mathrm{~b}$ & $18.72 b$ & $14.46 b$ & $33.18 \mathrm{~b}$ & $17.39 c$ \\
\hline 65 & $95 b$ & $100 \mathrm{a}$ & $19.44 \mathrm{~b}$ & $16.65 \mathrm{a}$ & 36.09 a & $18.83 c$ \\
\hline 70 & $98 a$ & $99 a$ & $20.23 a$ & $15.35 b$ & $35.58 \mathrm{a}$ & $20.56 c$ \\
\hline 75 & 99 a & $100 \mathrm{a}$ & $20.64 \mathrm{a}$ & $15.03 \mathrm{~b}$ & $35.68 \mathrm{a}$ & $22.60 c$ \\
\hline 80 & 99 a & 99 a & $21.11 \mathrm{a}$ & $15.21 b$ & $36.32 \mathrm{a}$ & $26.50 \mathrm{~b}$ \\
\hline C & $100 \mathrm{a}$ & $100 \mathrm{a}$ & $20.33 \mathrm{a}$ & $14.55 b$ & $34.88 \mathrm{~b}$ & $32.14 \mathrm{a}$ \\
\hline LSD & 3.1 & 2.1 & 1.4 & 1.7 & 2.3 & 4.7 \\
\hline CV (\%) & 5.9 & 4.4 & 5 & 8.2 & 4.7 & 14.8 \\
\hline Mean & 98 & 99 & 20.2 & 15 & 35.2 & 0.4 \\
\hline
\end{tabular}

* Same letters in the column do not differ from each other by the Skott-Knott test at $p<0.05$. ns: not significant ( $p>0.05)$. C: Control Treatment; LSD: least significant difference; CV (\%): Coefficient of variation.

light restriction started at stage 60 (beginning of anthesis), with vigor of $96 \%$ in the final evaluation (Table 2 ).

Length of the main root (RL) of the wheat seedlings decreased by $6.2,7.9$ and $4.4 \%$ in the seed lots whose plants were subject to the shading condition at stages 23,60 and 65 , respectively, when compared to those obtained from non-shaded plants, with $20.3 \mathrm{~cm}$ (Table 2). In relation to the length of the aerial part (shoot) of seedlings (SL), an increase of $14.5 \%$ was observed for the seed lots of wheat plants shaded in stage 65 (half of the complete anthesis), compared to the control, whose SLS was $14.5 \mathrm{~cm}$. Higher values were observed for the seminal roots, whose structure is the first to be emitted during the germination process, in relation to the aerial part (shoot).

Total length of wheat seedlings (TSL) of seed lots obtained from plants growing under shading in stages 30 (stem lengthening), 65 (half of complete anthesis), 70 (beginning of grain development), 75 (milky grain) and 80 (grain by mass) showed an increase by 2 to $4.1 \%$ compared to the control. The seedlings of wheat seeds from plants grown without shading condition had a TSL of $34.9 \mathrm{~cm}$.

The SDW (seedling dry weight) was significantly reduced by $84.8 \%$ for seed lots from wheat plants submitted to shading condition, regardless of the phenological stage at which it was started, compared to the control (32.14 mg). The greatest negative effects for wheat SDW were observed when light restriction was started between stages 45 to 75 , corresponding to booting and milky grain.

\section{Discussion}

The effect observed in TSW when limiting light to plants in the early stages of wheat crop development may be due to the effect of plant compensation, since the reduction in the number of seeds (data not shown) may have resulted in seeds with higher weight. The fact that the accumulation of biomass in the plant decreases, due to the lower intercepted photosynthetically active radiation, subsequently impacts the grain yield due to the lower remobilization of photoassimilates accumulated in the vegetative parts of the plant (Asseng et al., 2017).

Similar results were obtained for canola crop under $70 \%$ limitation of light during anthesis, whose variation in the increase in TSW was from 47 to $61 \%$, due to the higher rate and period of seed filling (Labra et al., 2017). The light restriction on plants during the anthesis period corroborates the results of Asseng et al. (2017) whose reduction in the number of wheat grains per area was 17 and $28 \%$, for shadings of 50 and $90 \%$, respectively, during the stages of booting up to anthesis. Therefore, the effect of light restriction in the periods close to flowering probably occurred due to the reduction of the photosynthetic rate of shaded plants (Guo et al., 2014), especially of the flag leaf, whose photoassimilates have a high relationship with the filling of wheat seeds (Guo et al., 2014).

The results observed for the FGC and GSI characterize the reduction of seed vigor, since lots with less vigor have lower germination speed and percentage of normal seedlings in the first count (Krzyzanowski et al., 1999) (Table 1). In a study with the herbicide metsulfuron-methyl on wheat plants in the tillering stages and $75 \%$ of the visible ears, Albrecht et al. (2010) observed that the vigor of produced seeds, evaluated by the FGC, varied between 84 and $94 \%$ of germination in the two growing seasons, lower percentage when applied in the reproductive stages. In relation to the GSI, Abati et al. (2014) found similar results, with an average of 12.7 with linear reduction when submitting seeds to higher levels of osmotic potential.

The EC assessment is efficient in classifying seed lots according to vigor (Sponchiado et al., 2014). The highest values of EC were observed for the seed lots with low vigor. Because they have less integrity of the integument membranes, less capacity for structuring after soaking in 
water and consequently greater release of exudates to the outside of the cells (Marcos Filho, 2015) (Table 2).

The EC values of wheat seeds from shaded plants were higher than that observed by Barbieri et al. (2013) that observed a variation of the EC of the seeds of four cultivars, with values between 15 and $30 \mu \mathrm{S} \mathrm{g}^{-1} \mathrm{~cm}^{-1}$, when evaluating the effect of population reduction of cultivars. In comparison to those observed in this research, seed lot control with 32.7 $\mu \mathrm{S} \mathrm{g}^{-1} \mathrm{~cm}^{-1}$ and plant seed lot shaded from the phenological stage 55 with $60.3 \mu \mathrm{S} \mathrm{g}^{-1} \mathrm{~cm}^{-1}$ (Table 2).

The $A A$ evaluations allowed to separate high and low vigor seed lots, in which deterioration of low vigor seeds is faster when subjected to the unfavorable condition of high temperature and relative humidity. However, the less vigorous lots reached a minimum of $93 \%$ in the AA. More intense reductions in seed vigor by the $A A$ test were observed for wheat cultivars BRS Umbu and BRS Tarumã when submitted to defoliation, in which the minimum percentage in AA was $46 \%$ and $49 \%$, respectively (Rodolfo et al., 2017), due to greater photosynthetic limitation.

In the CT, seeds with low vigor show greater loss of leachate during the reorganization of the membranes, due to their slower repair, when submitting in conditions of low temperature and high humidity (Marcos Filho, 2015). However, Brunes et al. (2015) did not observe a significant effect when studying the quality of the seeds with the application of Boron in wheat plants, although the results obtained were maintained above $90 \%$ of vigor by the test.

Observations in the batches that originated seedlings with reduced initial performance are related to the lower capacity to transform the reserve tissues and incorporate it into the embryonic axis (Bewley et al., 2013). According to Marcos Filho (2015), the evident demonstration of the decline in physiological potential is the reduction in the speed of germination of viable seeds, followed by the shorter length of seedlings and the occurrence of abnormality in germination.

The sensitivity of the reproductive stages of the wheat was observed due some treatments, which reflected in the final quality of the seeds produced. Likewise, different treatments for assessing vigor by seedling development were observed by Olivoto et al. (2017), with splice different nitrogen sources applied on wheat plants topdressing. These authors observed that the application of nitrogen in the most advanced stages results in greater accumulation of proteins in the seeds and, consequently, greater vigor of its seeds. As observed with the cultivar Quartz, in which the average for SLS was $8.9 \mathrm{~cm}$ with application of ammonium nitrate in the tillering, tillering and booting and, tillering, booting and flowering; for SRL, when applied to the taper, $10.8 \mathrm{~cm}$; and SDW with urea splitting in tillering and rubber and, tillering and flowering, with 12.6 and $12.1 \mathrm{mg}$ per seedling.

Considering the seed formation, vigor tests are carried out in batches to verify the intensity of the factors that reduce their physiological quality, in advance of the reduction of the germinative potential (Krzyzanowski et al., 1999). It is because seed lots may differ in vigor, even not differing in germination potential (Carvalho \& Nakagawa, 2012). Bellaloui et al. (2012) observed a reduction in the percentage of germination, depending on the genotypes, due to the lower temperature of the environment, when evaluating soybean seeds produced under a $50 \%$ limitation of light. In addition, there was a reduction in protein content, due supposedly to lower photosynthetic rate, assimilation of carbon and nitrogen.

Based on the relationship among the Zadoks phenological codes and the evaluated seed traits (Table 3), a positive relationship of the Zadoks code was observed only with $A B$. These results pointing to the light restriction imposed on plants during seed formation, lower quality seeds are produced on basis in abnormal seedlings $(A B)$ originated during germination process. Among the all seed quality traits evaluated, a positive association of TSW $\times$ G; TSW $\times$ AA; TSW $x$ RL; TSW x SDW; FGC x GSI; G x (TZ, GSI, AA, RL and TSL); AA $x(C T, R L$ and SDW); CT x TSL; RL $x$ TSL and RL and SDW. The negative relationship were observed of TSW $x$ DS, TSW $x E C ; G$ $x$ AB; G x DS; AB x GSI; DS x TZ; DS x AA; DS x CT; DS x TSL; TZ $x E C$ and $E C x$ SDW.

Table 3. Correlation of Pearson among Zadoks phenological stages (Zad), TSW, FGC, G, AB, DS, TZ, GSI, EC, AA, CT, RL, SL, TSL and SDW from wheat seeds produced under different periods of shading.

\begin{tabular}{|c|c|c|c|c|c|c|c|c|c|c|c|c|c|c|}
\hline$n \rightarrow$ & $\begin{array}{c}\text { TSW } \\
40 \\
\end{array}$ & $\begin{array}{c}\text { FGC } \\
40 \\
\end{array}$ & $\begin{array}{c}G \\
40 \\
\end{array}$ & $\begin{array}{l}A B \\
40 \\
\end{array}$ & $\begin{array}{l}\text { DS } \\
40 \\
\end{array}$ & $\begin{array}{l}\text { TZ } \\
40 \\
\end{array}$ & $\begin{array}{c}\text { GSI } \\
40 \\
\end{array}$ & $\begin{array}{l}\text { EC } \\
40 \\
\end{array}$ & $\begin{array}{l}A A \\
40 \\
\end{array}$ & $\begin{array}{l}\mathrm{CT} \\
40 \\
\end{array}$ & $\begin{array}{l}R L \\
80 \\
\end{array}$ & $\begin{array}{l}\text { SL } \\
80 \\
\end{array}$ & $\begin{array}{c}\text { TSL } \\
80 \\
\end{array}$ & $\begin{array}{c}\text { SDW } \\
80 \\
\end{array}$ \\
\hline Zad & -0.31 & -0.40 & -0.42 & 0.57 & 0.10 & -0.15 & -0.49 & -0.20 & -0.32 & -0.26 & 0.13 & 0.21 & 0.26 & -0.10 \\
\hline TSW & - & 0.24 & 0.69 & -0.52 & -0.56 & 0.35 & 0.31 & -0.59 & 0.73 & 0.48 & 0.61 & -0.22 & 0.38 & 0.92 \\
\hline G & & & - & -0.78 & -0.78 & 0.64 & 0.56 & -0.24 & 0.58 & 0.52 & 0.56 & 0.18 & 0.62 & 0.50 \\
\hline$A B$ & & & & - & 0.22 & -0.34 & -0.55 & 0.06 & -0.32 & -0.26 & -0.46 & 0.17 & -0.29 & -0.29 \\
\hline GSI & & & & & & & - & 0.17 & 0.42 & 0.28 & 0.37 & 0.09 & 0.39 & 0.08 \\
\hline $\mathrm{EC}$ & & & & & & & & - & -0.21 & 0.14 & -0.15 & 0.19 & 0.00 & -0.71 \\
\hline AA & & & & & & & & & - & 0.71 & 0.74 & -0.25 & 0.48 & 0.70 \\
\hline CT & & & & & & & & & & - & 0.50 & 0.29 & 0.65 & 0.42 \\
\hline$R L$ & & & & & & & & & & & - & -0.22 & 0.72 & 0.61 \\
\hline SL & & & & & & & & & & & & - & 0.51 & -0.26 \\
\hline
\end{tabular}

* The values in red color are negatively correlated and in blue color are positively correlated, by $T$ test $(t<0.05)$. 
Taken together, the results indicate sensitivity in the reproductive stage of wheat plants to define seed vigor due light restriction. Similar to results obtained by Rodolfo et al. (2017), who found no effects on the germination of the seeds produced, but there was a reduction in vigor, probably due to the lower content of carbohydrates (starch) in the seeds, by limiting the source-sink relationship of wheat plants, manipulating the source factor through defoliation between the tillering and booting stages. Thus, in the stages that precede the anthesis, the formation of floral structures occurs (Marcos Filho, 2015), later double fertilization, that is, the union of the nuclei spermatic $(n)$ with the oosphere $(n)$ and the polar nuclei $(2 n)$, to then start cell division, growth of the zygote $(2 n)$ and the reserve tissue, the endosperm (3n) (Berger, 2003).

The endosperm is the tissue that supports the development and germination of the embryo originating from the fertilization of one of the male gametes that arrive through the pollen tube and the central cell of the embryonic sac (Berger, 2003). It develops in the central region of the embryonic sac through intense cell divisions (Bewley et al., 2013). The efficient accumulation of carbohydrates in the seed is necessary for the proper development of the embryo, providing chemical energy until the establishment of the autotrophic seedling (Goffman et al., 2005). In this way, the photosynthetic activity of the flag leaf must be sufficient to supply photosynthesis for the formation and filling of seeds, even under reduced light, and then, there is no damage in the formation of this seed (Xu et al., 2016), because more than $60 \%$ of the photosynthesis product (glucose) destined for a seed is produced by the flag leaf (Fang et al., 2006).

\section{Conclusions}

The continuous shading in wheat plants does not interfere with the germination of the seeds produced, but there is a negative effect on the seed vigor and the thousand seeds weight, depending on the phenological stage that light restriction starts.

In general, under shading the physiological quality of the seeds produced is high, except, when the shading starts between the rubber and the anthesis (stages 45 to 65), wheat plants are sensitive to light restriction. This can be useful in collaboration to growers for definition of sowing schedule, as an escape for critical stages.

\section{Acknowledgments}

The authors would like to thank CNPq, CAPES, FAPESC/ UDESC/PAP and UNIEDU/FUMDES for their financial support to the present research and the scholarships granted to the authors.

\section{Compliance with Ethical Standards}

Funding: Conselho Nacional de Desenvolvimento Científico e Tecnológico (CNPq), Coordenação de Aperfeiçoamento de
Pessoal de Nível Superior - Brasil (CAPES) - Finance Code 001, FAPESC/UDESC/PAP and UNIEDU/FUMDES.

Conflict of interest: The authors declare no conflict of interest.

Author contribution: Conceptualization: CAS, CC, RK, ERS; Data curation: CAS, CC; Formal analysis: CC; Funding acquisition: CAS; Investigation: CC, ERS, RK, CS; Methodology: CC, CMMC; Project administration: CAS, CC; Resources: CAS; Supervision: CAS; Validation: CAS, CC, RK, ERS; CS; Visualization: CAS, CC; Writing - original draft: CC; Writing review \& editing: CAS, CC, CMMC.

\section{Literature Cited}

Abati, J.; Brzezinski, C. R.; Zucareli, C.; Henning, F. A.; Alves, V. F. N.; Garcia, V. V. Qualidade fisiológica de sementes de trigo tratadas com biorregulador em condições de restrição hídrica. Informativo Abrates, v.24, n.1, p.32-36, 2014. https://ainfo.cnptia.embrapa. $\mathrm{br} /$ digital/bitstream/item/127761/1/Qualidade-fisiologica-desementes-de-trigo-tratadas-com.pdf. 29 Mar. 2020.

Albrecht, A. J. P.; Albrecht, L. P. Metsulfuron-methyl no desempenho agronômico e na qualidade das sementes de trigo. Revista Brasileira de Herbicidas, v.9, n.2, p.54-62, 2010. https://doi. org/10.7824/rbh.v9i2.81.

Arenas-Corraliza, M. G.; Rolo, V.; López-Díaz, M. L.; Moreno, G. Wheat and barley can increase grain yield in shade through acclimation of physiological and morphological traits in Mediterranean conditions. Scientific Reports, v.9, n.1, p.9547-9556, 2019. https://doi.org/10.1038/s41598-019-46027-9.

Asseng, S.; Kassie, B. T.; Labra, M. H.; Amador, C.; Calderini, D. F. Simulating the impact of source-sink manipulations in wheat. Field Crops Research, v.202, n.1, p.47-56, 2017. https://doi. org/10.1016/j.fcr.2016.04.031

Barbieri, A. P. P.; Martin, T. N.; Mertz, L. M.; Nunes, U. R.; Conceição, G. M. Redução populacional de trigo no rendimento e na qualidade fisiológica das sementes. Ciência Agronômica, v.44, n.4, p.724731, 2013. https://doi.org/10.1590/S1806-66902013000400008

Bellaloui, N.; Smith, J. R.; Gillen, A. M.; Fisher D. K.; Mengistu, A. Effect of shade on seed protein, oil, fatty acids, and minerals in soybean lines varying in seed germinability in the early soybean production system. American Journal of Plant Sciences, v.3, n.1, p.84-95, 2012. https://doi.org/10.4236/ajps.2012.31008.

Berger, F. Endosperm: the crossroad of seed development. Current Opinion in Plant Biology, v.6, n.1, p.42-50, 2003. https://doi. org/10.1016/S1369526602000043.

Bewley, J. D.; Bradford, K.; Hilhorst, H.; Nonogaki, H. Seeds: Physiology of development, germination and dormancy. 3.ed. Nova York: Springer, 2013. 392p.

Brasil. Ministério da Agricultura, Pecuária e Abastecimento. Regras para Análise de Sementes. Brasília: ACS, 2009. 398p.

Brunes, A. P.; Oliveira, S.; Lemes, E. S.; Tavares, L. C.; Gehling, V. M.; Dias, L. W.; Villela, F. A. Adubação boratada e produção de sementes de trigo. Ciência Rural, v.45, n.9, p.1572-1578, 2015. https://doi.org/10.1590/0103-8478cr20131676. 
Carvalho, N. M.; Nakagawa, J. Sementes: ciência, tecnologia e produção. 5 ed. Jaboticabal: FUNEP, 2012. 590p.

Comissão de Química e Fertilidade do Solo - CQFS RS/SC. Manual de adubação e de calagem para os estados do Rio Grande do Sul e Santa Catarina. Porto Alegre: SBCS - Núcleo Regional Sul/UFRGS, 2016. 376p.

Companhia Nacional de Abastecimento - Conab. Acompanhamento da safra brasileira de grãos. Brasília: Conab, 2020. v.7, n.7, 104 p. https://www.conab.gov.br/info-agro/safras/graos/boletim-dasafra-de-graos/item/download/31573_06a33dea1d278bc862e3 efce50226386. 18 Nov. 2020.

Custódio, M. S.; Berlato, M. A.; Fontana, D. C. Nebulosidade diurna no Rio Grande do Sul, Brasil: climatologia e tendência temporal. Pesquisa Agropecuária Gaúcha, v.15, n.1, p.45-52, 2009. http:// www.revistapag.fepagro.rs.gov.br/Pages/revista. 05 Nov. 2020.

Fang, Q. X.; Chen, Y. H.; Li, Q. Q.; Yu, S. Z.; Luo, Y.; Yu, Q.; Ouyang, Z. Effects of soil moisture on radiation utilization during late growth stages and water use efficiency of winter wheat. Acta Agronomica Sinica, v.32, n.6, p.861-866, 2006. http://zwxb.chinacrops.org/ EN/Y2006/V32/I06/861. 07 Dec. 2020.

Ferreira, D. F. SISVAR: um programa para análise e ensaio de estatística. Revista Symposium, v.6, n.2, p.36-41, 2011. https:// doi.org/10.1590/S1413-70542011000600001.

Food and Agriculture Organization of the United Nations - FAO. Agricultural Market Information System - Statistics at a glance. http://www.amis-outlook.org/home/en/. 18 Nov. 2020.

Goffman, F. D.; Alonso, A. P.; Schwender, J.; Shachar-Hill, Y.; Ohlrogge, J. B. Light enables a very high efficiency of carbon storage in development embryos of rapeseed. Plant Physiology, v.138, n.4, p.2269-2279, 2005. https://doi.org/10.1104/pp.105.063628.

Guo, Z.; Yu, Z.; Wang, D.; Shi, Y. Photosynthesis and winter wheat yield responses to supplemental irrigation soil layers. Field Crops Research, v.166, p.102- 111, 2014. https://doi.org/10.1016/j. fcr.2014.06.004.

Krzyzanowski, F. C., Vieira, R. D., França-Neto, J. B. Vigor de sementes: Conceitos e testes. Londrina: ABRATES, 1999. 218p.

Labra, M. H.; Struik, P. C.; Evers, J. B.; Calderini, D. F. Plasticity of seed weight compensates reductions in seed number of oilseed rape in response to shading at flowering. European Journal of Agronomy, v.84, p.113-124, 2017. https://doi.org/10.1016/j.eja.2016.12.011.
Li, H.; Jiang, D.; Wollenwebwe, B.; Dai, T.; Cao, W. Effects of shading on morphology, physiology and grain yield of winter wheat. European Journal of Agronomy, v.33, n.4, p.267-275, 2010. https://doi.org/10.1016/j.eja.2010.07.002.

Maguire, J. D. Speed of germination-aid in selection and evaluation for seedling emergence and vigor. Crop Science, v.2, n.1, p.176-177, 1962. https://doi.org/10.2135/ cropsci1962.0011183X000200020033x.

Marcos Filho, J Seed vigor testing: an overview of the past, present and future perspective. Scientia Agrícola, v.72, n.4, p.363-374, 2015. https://doi.org/10.1590/0103-9016-2015-0007.

Mu, H.; Jiang, D.; Wollenweber, B.; Dai, T.; Jing, Q.; Cao, W. Long-term low radiation decreases leaf photosynthesis, photochemical efficiency and grain yield in winter wheat. Journal of Agronomy and Crop Science, v.196, n.1, p.38-47, 2010. https://doi. org/10.1111/j.1439-037X.2009.00394.x.

Olivoto, T.; Nardino, M.; Carvalho, I. R.; Ferrari, M.; Pelegrin, A. J.; Szareski, V. J.; Souza, V. Q. Parcelamento e fontes de nitrogênio na qualidade fisiológica de sementes de trigo. Revista de Ciências Agroveterinárias, v.16, n.4, p.345-356, 2017. https://doi. org/10.5965/223811711642017345.

Rodolfo, G. R.; Souza, C. A.; Coelho, C. M. M.; Belizario, K. K. Physiological quality of dual-purpose wheat seeds from plants subjected to artificial defoliation. Ciência Rural, v. 47, n.1, e20151582, 2017. https://doi.org/10.1590/01038478 cr20151582.

Sponchiado, J. C.; Souza, C. A.; Coelho, C. M. M. Teste de condutividade elétrica para determinação do potencial fisiológico de sementes de aveia branca. Semina: Ciências Agrárias, v.35, n.4, p.2405-2414, 2014 . https://doi.org/10.5433/16790359.2014v35n4Suplp2405.

Xu, C.; Tao, H. B.; Wang, P.; Wang, Z. L. Slight shading after anthesis increases photosynthetic productivity and grain yield of winter wheat (Triticum aestivum L.) due to the delaying of leaf senescence. Journal of Integrative Agriculture, v.15, n.1, p.63-75, 2016. https://doi.org/10.1016/S2095-3119(15)61047-4.

Zadoks, J. C.; Chang, T. T.; Konzak, C. F. A decimal code for the growth stages of cereals. Weed Research, v.14, n.6, p.415-421, 1974. https://doi.org/10.1111/j.1365-3180.1974.tb01084.x. 